\title{
GIARDIA AND CRYPTOSPORIDIUM IN RED FOXES (VULPES VULPES): SCREENING FOR COPROANTIGENS IN A POPULATION OF CENTRAL ITALY AND MINI-REVIEW OF THE LITERATURE
}

\author{
Roberto Amerigo Papini ${ }^{1}$, Ranieri Verin ${ }^{2}$ \\ ${ }^{1}$ Department of Veterinary Sciences, University of Pisa, \\ Viale delle Piagge 2, 56124 Pisa, Italy \\ ${ }^{2}$ Department of Veterinary Pathology and Public Health, Institute of Veterinary Science, \\ Leahurst Campus, University of Liverpool, Chester High Road, \\ CH64 7TE, Neston, United Kingdom
}

Received 16 April 2018; Received in revised form 27 November 2018; Accepted 29 January 2019

\begin{abstract}
Giardia and Cryptosporidium are common protozoan parasites affecting several animal species and humans. The aim of this survey was to investigate, for the first time, their prevalence in red fox (Vulpes vulpes) faecal samples in central Italy. Seventy-one red foxes of different ages and sexes were examined for antigenic detection of Giardia and Cryptosporidium in fecal samples by means of a commercial rapid immunochromatographic test. The sample was randomly selected from foxes culled during a population control program. They were divided into groups based on sex and age $(\leq 1$-year-old and $>1$-year-old). Five (7\%) and one (1.4\%) out of 71 fecal samples were positive for the Giardia or Cryptosporidium antigens by immunochromatographic assay, respectively, and no coinfections were observed. The present prevalence rates of Giardia and Cryptosporidium antigens in faeces from $V$. vulpes suggest that this host species is likely to play only a limited role in the spread of the two protozoa in the study area. A concise review of the literature related to Giardia and Cryptosporidium in $V$. vulpes is presented.
\end{abstract}

Key words: Giardia, Cryptosporidium, coproantigens, red fox, Vulpes vulpes

\section{INTRODUCTION}

The protozoa Giardia duodenalis (Sarcomastigophora: Hexamitidae) and Cryptosporidium spp (Apicomplexa: Cryptospo ridiidae) are among the most common intestinal parasites in humans and many other animal species, including pets, livestock, and wildlife (1, 2). They have a direct life cycle. Infected hosts shed environmentally resistant (oo)cysts in their faeces. (Oo)cysts are immediately infectious and may retain their infectivity for long periods.

Corresponding author: Prof. Roberto Amerigo Papini, DVM, EVPC Dipl E-mail address: roberto.amerigo.papini@unipi.it

Present address: Department of Veterinary Sciences, University of Pisa, Viale delle Piagge 2, 56124 Pisa, Italy

Phone: +39050 221 6948; Fax: +39050 2216941

Copyright: (C) 2019 Papini R.A. This is an open-access article published under the terms of the Creative Commons Attribution License which permits unrestricted use, distribution, and reproduction in any medium, provided the original author and source are credited.

Competing Interests: The authors have declared that no competing interests exist.

Available Online First: 15 February 2019

Published on: 15 March 2019

https://doi.org/10.2478/macvetrev-2019-0013
Transmission occurs via the faecal-oral route by the ingestion of (oo)cysts from contaminated water and food. Human-to-human and animal-to-human transmissions are also frequent $(1,2)$. Giardiasis and cryptosporidiosis are usually asymptomatic. Clinical manifestations in humans, when present, can vary from acute self-limiting diarrhoea to chronic gastrointestinal disease with persistent diarrhea, nausea, vomiting, fever, abdominal pain, malabsorption, malnutrition, and delayed growth in children $(1,2)$. Cryptosporidiosis can be a potentially life-threatening disease in immunocompromised individuals (2), as well as in calves (3) because of the rapid loss of fluids from profuse watery diarrhoea.

Red foxes (Vulpes vulpes) are widespread worldwide (4). Following successful oral antirabies vaccination programs, their number has increased throughout Europe (5), including in Italy (6), reaching high population densities in urban areas (7). Red foxes have been previously reported 
as potential reservoirs of serious zoonotic parasites (8), including Giardia and Cryptosporidium (9 - 18), and may be a source for transmission of pathogens to humans and animals (19). Because of the growing population of red foxes in urban areas (7), humans and domestic animals may be increasingly exposed to the risk of infection with Giardia and Cryptosporidium from environments contaminated by (oo)cysts shed in the faeces of infected red foxes (19).

In the present work, samples from red foxes culled in Italy were screened by a commercial immunochromatographic rapid diagnostic test for the occurrence of Giardia and Cryptosporidium coproantigens, in order to investigate, for the first time in Italy, the prevalence of the two protozoa in this host species. This paper presents the results as well as a short review of the literature worldwide for species and genotypes of Giardia and Cryptosporidium in $V$. vulpes.

\section{MATERIAL AND METHODS}

Study area, animals examined, and collection of faecal samples

Between September 2016 and January 2017, fresh faecal specimens (at least $3 \mathrm{gr}$ ) were collected from the rectums of 71 red foxes legally shot by hunters, during a population control program in the province of Pisa $\left(43^{\circ} 43^{\prime} \mathrm{N} 10^{\circ} 24^{\prime} \mathrm{E}\right)$, Tuscany, central Italy. Woods and hilly sites characterize the sampling areas with a high density of red foxes (1.2-1.6 foxes $/ \mathrm{km} 2)$. The sex of the animals was determined and their age was assessed by crystalline lens weight (20). Foxes were classified as juveniles $(\leq 1$-year-old) or adults ( $>1$-year-old). Overall, fecal samples from 41 males, 30 females, 46 adults, and 25 juveniles were collected. Samples were directly placed in plastic containers, refrigerated at $+4^{\circ} \mathrm{C}$, and tested within 48 hours.

\section{Immunochromatographic tests}

Each faecal sample was tested separately by the Xspect ${ }^{\circledR}$ Giardia/Cryptosporidium test (Remel Thermo Scientific, Santa Fe Drive, Lenexa, KS, USA) according to the manufacturer's guidelines. The Xspect ${ }^{\circledR}$ Giardia/Cryptosporidium kit is a commercially available qualitative immunoassay. It is licensed to simultaneously detect the presence of the Giardia cyst antigen and Cryptosporidium oocyst antigen in preserved and unpreserved fecal specimens, and is intended for use in humans. Performance characteristics provided by the manufacturer report sensitivity values of $95.8 \%$ and $96.4 \%$ with a specificity of $98.5 \%$ for Giardia and Cryptosporidium, respectively, in comparison to microscopy (https://www.thermofisher.com/order/ catalog/product/R2450520). The test is easy to use and requires minimal equipment and training. Results are visually read after a relatively short incubation time of 15 minutes. It is thus suitable for use in field situations where there is a need for rapid diagnostic information with limited time, technical support, and resources.

\section{Statistical analysis}

Prevalence values were determined as the number of positive animals/number of examined animals $\mathrm{X}$ 100 with the corresponding $95 \%$ confidence intervals (95\% CI). Different prevalence values according to sex and age groups were compared with the use of the Fisher's exact test. Differences were considered significant when $\mathrm{P}<0.05$.

Table 1. Number of positive samples, prevalence, and $95 \%$ confidence intervals for the occurrence of Giardia and Cryptosporidium in faeces from red foxes (Vulpes vulpes) in Italy as determined by coproantigen detection

\begin{tabular}{|c|c|c|c|c|c|c|c|c|c|c|}
\hline \multirow[t]{2}{*}{ Subjects } & & \multicolumn{3}{|c|}{ Giardia } & \multicolumn{3}{|c|}{ Cryptosporidium } & \multicolumn{3}{|c|}{ Total } \\
\hline & & $\begin{array}{c}\text { Positive } \\
\text { No. }\end{array}$ & Prevalence & $\begin{array}{c}95 \% \\
\text { CI }\end{array}$ & $\begin{array}{c}\text { Positive } \\
\text { No. }\end{array}$ & Prevalence & $95 \%$ CI & $\begin{array}{c}\text { Positive } \\
\text { No. }\end{array}$ & Prevalence & $95 \% \mathrm{CI}$ \\
\hline \multirow[t]{2}{*}{ Sex } & $\begin{array}{l}\text { Males } \\
(n=41)\end{array}$ & $2^{\text {a }}$ & $4.9 \%$ & $\begin{array}{c}0.0- \\
11.5 \%\end{array}$ & $1^{\mathrm{c}}$ & $2.4 \%$ & $0.0-7.2 \%$ & 3 & $7.3 \%$ & $\begin{array}{c}0.0- \\
15.3 \%\end{array}$ \\
\hline & $\begin{array}{c}\text { Females } \\
(n=30)\end{array}$ & $3^{a}$ & $10 \%$ & $\begin{array}{c}0.0- \\
20.7 \%\end{array}$ & $0^{\mathrm{c}}$ & $0.0 \%$ & $0.0 \%$ & 3 & $10 \%$ & $\begin{array}{c}0.0- \\
20.7 \%\end{array}$ \\
\hline \multirow[t]{2}{*}{ Age } & $\begin{array}{l}\text { Adults } \\
(n=46)\end{array}$ & $2^{b}$ & $4.3 \%$ & $\begin{array}{c}0.0- \\
10.2 \%\end{array}$ & $1^{\mathrm{d}}$ & $2.2 \%$ & $0.0-6.4 \%$ & 3 & $6.5 \%$ & $\begin{array}{c}0.0- \\
13.7 \%\end{array}$ \\
\hline & $\begin{array}{c}\text { Juveniles } \\
(\mathbf{n}=\mathbf{2 5})\end{array}$ & $3^{b}$ & $12 \%$ & $\begin{array}{c}0.0- \\
24.7 \%\end{array}$ & $0^{\mathrm{d}}$ & $0.0 \%$ & $0.0 \%$ & 3 & $12 \%$ & $\begin{array}{c}0.0- \\
24.7 \%\end{array}$ \\
\hline $\begin{array}{c}\text { Total } \\
(n=71)\end{array}$ & & 5 & $7 \%$ & $\begin{array}{l}1.1- \\
13 \%\end{array}$ & 1 & $1.4 \%$ & $0.0-4.1 \%$ & 6 & $8.4 \%$ & $2-14.9 \%$ \\
\hline
\end{tabular}

a, b, c, d No statistically significant differences by Fisher's exact test: ${ }^{a} \mathrm{P}=0.64 ;{ }^{b} \mathrm{P}=0.33 ;{ }^{\mathrm{c}, \mathrm{d}} \mathrm{P}=1.00$ 
Table 2. Summary of literature data on the molecular characterization of Giardia duodenalis and Cryptosporidium species/genotypes in free-ranging red foxes (Vulpes vulpes)

\begin{tabular}{|c|c|c|c|c|c|c|}
\hline \multirow[t]{2}{*}{ Country } & \multirow{2}{*}{$\begin{array}{c}\text { No. of } \\
\text { samples } \\
\text { examined }\end{array}$} & \multicolumn{3}{|c|}{ Giardia duodenalis } & \multirow{2}{*}{$\begin{array}{c}\text { Cryptosporidium } \\
\text { Species/genotypes }\end{array}$} & \multirow[t]{2}{*}{ Reference no. } \\
\hline & & $\begin{array}{l}\text { Positive } \\
\text { samples }\end{array}$ & Assemblages & $\begin{array}{l}\text { Positive } \\
\text { samples }\end{array}$ & & \\
\hline USA & 76 & ND & ND & 6 & $\begin{array}{l}\text { Cryptosporidium canis fox genotype } \\
\qquad(\mathrm{n}=4) \\
\text { Cryptosporidium canis dog genotype } \\
(\mathrm{n}=1) \\
\text { Muskrat genotype } \mathrm{I}(\mathrm{n}=1)\end{array}$ & 9 \\
\hline Norway & 269 & 13 & $A(n=5) B(n=2)$ & 6 & ND & 10 \\
\hline UK & 124 & ND & ND & 10 & Cryptosporidium parvum $(\mathrm{n}=2)$ & 11 \\
\hline Croatia & 66 & 3 & $\mathrm{~A}(\mathrm{n}=1)$ & ND & ND & 12 \\
\hline Australia & 19 & 6 & $\begin{array}{c}\mathrm{D}(\mathrm{n}=1) \mathrm{E}(\mathrm{n}=1) \\
\mathrm{A} / \mathrm{D}(\mathrm{n}=1) \mathrm{A} / \mathrm{E} \\
(\mathrm{n}=3)\end{array}$ & 2 & $\begin{array}{c}\text { Cryptosporidium canis }(\mathrm{n}=1) \\
\text { Cryptosporidium macropodum }(\mathrm{n}=1)\end{array}$ & 13 \\
\hline UK & 30 & ND & ND & 4 & $\begin{array}{l}\text { Cryptosporidium bovis }(\mathrm{n}=1) \\
\text { Cryptosporidium parvum }(\mathrm{n}=1) \\
\text { Muskrat genotype II }(\mathrm{n}=1)\end{array}$ & 14 \\
\hline Australia & 23 & 0 & ND & 1 & Cryptosporidium canis $(\mathrm{n}=1)$ & 16 \\
\hline Sweden & 104 & 14 & $\mathrm{~B}(\mathrm{n}=4)$ & ND & ND & 17 \\
\hline Spain & 87 & 7 & ND & 7 & $\begin{array}{l}\text { Cryptosporidium parvum }(\mathrm{n}=3) \\
\text { Cryptosporidium canis }(\mathrm{n}=2) \\
\text { Cryptosporidium felis }(\mathrm{n}=1) \\
\text { Cryptosporidium ubiquitum }(\mathrm{n}=1)\end{array}$ & 18 \\
\hline
\end{tabular}

$\mathrm{ND}=$ Not determined

\section{RESULTS}

Overall, six (8.4\%, 95\% CI: 2-14.9\%) samples were positive for coproantigens, with a moderate prevalence $(7 \%, 95 \%$ CI: $1.1-13 \%)$ for Giardia and low prevalence $(1.4 \%, 95 \%$ CI: $0-4.1 \%)$ for Cryptosporidium.

Among the five Giardia positive red foxes, three were juveniles (two females and one male) and two were adults (one male and one female). The only Cryptosporidium positive red fox was an adult male. Coinfections with both parasites were not detected. Table 1 shows the distribution of positive samples by age and sex. No significant differences related to age and sex groups were found. All the foxes appeared to have been in good body condition, as determined by fat deposits and body weight.

\section{DISCUSSION}

Variations in the prevalence of Giardia and Cryptosporidium in red foxes from different geographical areas have been widely reported. There are considerable differences from country to country and sometimes even between different regions within the same country. The present prevalence rate for Giardia (7\%) falls in the prevalence range previously reported in red foxes, varying from $0 \%$ in Australia (16) to $44 \%$ Sweden (17). With respect to Cryptosporidium, the present prevalence rate (1.2\%) is the lowest detected among those reported for red foxes to date, varying from $2 \%$ in Norway (10) to $38.7 \%$ in the Slovak Republic (15).

It is difficult to compare prevalence data from different studies, as the results may vary depending on the diagnostic performance of the different tests used, the geographical features of the study area, the animal population examined, and the sampling method used. In concordance with the results of other studies $(10,13)$, the present prevalence of Cryptosporidium was consistently lower than that found for Giardia (1.4\% vs. 7\%). According to some authors (10), the spontaneous recovery of Cryptosporidium infection in red foxes may be complete within relatively short time periods. Conversely, Giardia infection usually takes longer to achieve complete recovery and thus may be more frequently identified in single faecal samples.

Although marketed for humans, the Xspect ${ }^{\circledR}$ Giardia/Cryptosporidium test has previously been used in veterinary medicine for the detection of 
Giardia and Cryptosporidium in diarrheic or nondiarrheic sheltered cats (21) and pet squirrels (22). When compared with direct immunofluorescence in fecal specimens from naturally-infected cats, this rapid test showed sensitivities of 79.4\% (95\% CI: $62.1-91.3 \%)$ for Giardia and $42.9 \%(95 \% \mathrm{CI}$ : 17.7-71.1\%) for Cryptosporidium. These values were offset by specificities as high as $99 \%(95 \%$ CI: $97.2-99.8 \%$ ) and $99.1 \%$ (95\% CI: 97.4-99.8\%), respectively (21). At present, it is unknown whether or not the test works in stool specimens from red foxes similarly to those from cats.

Regarding results in cats, the test may be highly effective in identifying uninfected animals but moderately or fairly effective in identifying infected ones. In addition, immunoassays commercialized for the detection of Giardia and Cryptosporidium in humans are validated for use with human isolates. Red foxes have been reported to be frequently infected with $G$. duodenalis assemblages and Cryptosporidium species other than those most commonly found in humans (Table 2). Genetic heterogeneity of Giardia and Cryptosporidium isolates between humans and animals could affect the performance characteristics of immunoassays for human specimens when used in animals. These factors do not necessarily mean that the Xspect ${ }^{\circledR}$ Giardia/Cryptosporidium test should not be used in veterinary medicine, but rather that results in animals should be interpreted more cautiously, and a more sensitive additional method may be advisable to confirm negative results.

In the present survey, we found a moderate prevalence of Giardia and a very low prevalence of Cryptosporidium compared with most of the published findings from other red fox populations. This could in part be the result of under-diagnosis because the immunochromatographic test might have missed some true positive results. Thus, we cannot rule out that the actual prevalence of Giardia and Cryptosporidium was higher than reported here.

Some studies have used molecular analyses and sequencing to identify $G$. duodenalis genotypes or/and Cryptosporidium species and genotypes in faecal samples from red foxes. The results have demonstrated that red foxes may shed a wide variety of both host-adapted and potentially zoonotic isolates. A summary of these results is presented in Table 2. Since no genetic studies have assessed the species and genotypes of the two protozoa occurring in the examined red fox population, the public health implications, if any, of the findings presented here remain undetermined.
It is worth noting that red foxes may ingest (oo) cysts by eating infected prey. For instance, Giardia and Cryptosporidium are routinely found in small rodents (23), which are a common part of the fox diet. Because it is difficult to distinguish between a mechanical passage of ingested (oo)cysts and an actual infection of the host, the question may arise as to whether foxes are actually infected and subsequently excrete (oo) cysts or whether (oo)cysts are merely passing through their digestive tract $(15,19)$. We believe that it is likely that at least some of the previously reported findings were not due to natural, true infections.

\section{CONCLUSION}

The results of the present study show that red foxes culled in an area of central Italy shed Giardia cysts and Cryptosporidium oocysts in their faeces with moderate and low prevalence rates, respectively. Red foxes are therefore unlikely to play an important role as a source for environmental contamination with (oo)cysts and for transmission of these parasites to other wildlife, domestic animals, and humans in the study area. The present findings complement and expand previous knowledge on the presence of Giardia and Cryptosporidium in free-ranging red foxes. To the best of our knowledge, this is the first report on the occurrence of Cryptosporidium and Giardia in a red fox population in Italy.

\section{CONFLICT OF INTEREST}

The authors declared that they have no potential conflict of interest with respect to the authorship and/or publication of this article.

\section{ACKNOWLEDGEMENTS}

The authors wish to thank all the hunters engaged in fox control program within the territorial hunting areas of the Pisa province, named ATC 14 and ATC 15, for allowing us to collect animal data and to sample culled red foxes.

\section{REFERENCES}

1. Feng, Y., Xiao, L. (2011). Zoonotic potential and molecular epidemiology of Giardia species and giardiasis. Clin Microbiol Rev. 24(1): 110-140.

https://doi.org/10.1128/CMR.00033-10

PMid:21233509 PMCid:PMC3021202 
2. Leitch, G. J., He, Q. (2011). Cryptosporidiosis-an overview. J Biomed Res. 25(1): 1-16. https://doi.org/10.1016/S1674-8301(11)60001-8

3. Thomson, S., Hamilton, C. A., Hope, J. C., Katzer, F., Mabbott, N. A., Morrison, L. J., Innes, E. A. (2017). Bovine cryptosporidiosis: impact, host-parasite interaction and control strategies. Vet Res. 48(1): 42. https://doi.org/10.1186/s13567-017-0447-0 PMid:28800747 PMCid:PMC5553596

4. Hoffmann, M., Sillero-Zubiri, C. (2016). Vulpes vulpes. [Internet]. The IUCN red list of threatened species 2016: e.T23062A46190249. [cited April 5, 2018].

http://dx.doi.org/10.2305/IUCN.UK.2016-1.RLTS. T23062A46190249.en.

5. Freuling, C. M., Hampson, K., Selhorst, T., Schröder, R., Meslin, F. X., Mettenleiter, T. C., Müller T. (2013). The elimination of fox rabies from Europe: determinants of success and lessons for the future. Philos Trans R Soc Lond B Biol Sci. 368 (1623): 20120142.

https://doi.org/10.1098/rstb.2012.0142

PMid:23798690 PMCid:PMC3720040

6. Sartore, S., Mulatti, P., Trestini, S., Lorenzetto, M., Gagliazzo, L., Marangon, S., Bonfanti, L. (2018). The economic implications of sylvatic rabies eradication in Italy. Zoonoses Public Health 65(1): 147-157.

https://doi.org/10.1111/zph.12383

PMid:28795513

7. Reperant, L. A., Hegglin, D., Fischer, C., Kohler, L., Weber, J. M., Deplazes, P. (2007). Influence of urbanization on the epidemiology of intestinal helminths of the red fox (Vulpes vulpes) in Geneva, Switzerland. Parasitol Res. 101(3): 605-611. https://doi.org/10.1007/s00436-007-0520-0 PMid:17393184

8. Karamon, J., Dabrowska, J., Kochanowski, M., Samorek-Pieróg, M., Sroka, J., et al. (2018). Prevalence of intestinal helminths of red foxes (Vulpes vulpes) in central Europe (Poland): a significant zoonotic threat. Parasit Vectors. 11, 436. https://doi.org/10.1186/s13071-018-3021-3 PMid:30055657 PMCid:PMC6064108

9. Zhou, L., Fayer, R., Trout, J. M., Ryan, U. M., Schaefer, F. W., Xiao, L. (2004). Genotypes of Cryptosporidium species infecting fur-bearing mammals differ from those of species infecting humans. Appl Environ Microbiol. 70(12): 7574-7577. https://doi.org/10.1128/AEM.70.12.7574-7577.2004 PMid:15574965 PMCid:PMC535153
10. Hamnes, I. S., Gjerde, B. K., Forberg, T., Robertson, L. J. (2007). Occurrence of Giardia and Cryptosporidium in Norwegian red foxes (Vulpes vulpes). Vet Parasitol. 143(3-4): 347-353.

https://doi.org/10.1016/j.vetpar.2006.08.032 PMid:17045400

11. Nagano, Y., Finn, M. B., Lowery, C. J., Murphy, T., Moriarty, J., Power, E., et al. (2007). Occurrence of Cryptosporidium parvum and bacterial pathogens in faecal material in the red fox (Vulpes vulpes) population. Vet Res Comm. 31(5): 559-564.

https://doi.org/10.1007/s11259-007-3519-1 PMid:17225081

12. Beck, R., Sprong, H., Lucinger, S., Pozio, E., Cacció S. M. (2011). A large survey of Croatian wild mammals for Giardia duodenalis reveals a low prevalence and limited zoonotic potential. Vector Borne Zoonotic Dis. 11(8): 1049-1055. https://doi.org/10.1089/vbz.2010.0113 PMid:21142957

13. Ng, J., Yang, R., Whiffin, V., Cox, P., Ryan, U. (2011). Identification of zoonotic Cryptosporidium and Giardia genotypes infecting animals in Sidney's water catchments. Exp Parasitol. 128(2): 138-144. https://doi.org/10.1016/j.exppara.2011.02.013 PMid:21334325

14. Robinson, G., Chalmers, R. M., Stapleton, C., Palmer, S. R., Watkins, J., Francis, C., Kay, D. (2011). A whole water catchment approach to investigating the origin and distribution of Cryptosporidium species. J Appl Microbiol. 111(3): 717-730. https://doi.org/10.1111/j.1365-2672.2011.05068.x PMid:21649804

15. Ravaszova, P., Halanova, M., Goldova, M., Valencakova, A., Malcekova, B., Hurníková, Z., Halan, M. (2012). Occurrence of Cryptosporidium spp. in red foxes and brown bear in the Slovak Republic. Parasitol Res. 110(1): 469-471. https://doi.org/10.1007/s00436-011-2523-0 PMid:21744018

16. Nolan, M. J., Jexa, A. R., Koehlera, A. V., Haydon, S. R., Stevens, M. A., Gasser, R. B. (2013). Molecularbased investigation of Cryptosporidium and Giardia from animals in water catchments in southeastern Australia. Water Res. 47(5): 1726-1740. https://doi.org/10.1016/j.watres.2012.12.027 PMid:23357792

17. Debenham, J. J., Landuyt, H., Troell, K., Tysnes, K., Robertson, L. J. (2017). Occurrence of Giardia in Swedish red foxes (Vulpes vulpes). J Wildl Dis. 53(3): 649-652.

https://doi.org/10.7589/2017-01-002

PMid:28362140 
18. Mateo, M., de Mingo, M. H., de Lucio, A., Morales, L., Balseiro, A., Espí, A., et al. (2017). Occurrence and molecular genotyping of Giardia duodenalis and Cryptosporidium spp. in wild mesocarnivores in Spain. Vet Parasitol. 235, 86-93.

https://doi.org/10.1016/j.vetpar.2017.01.016

PMid:28215875

19. Otranto, D., Cantacessi, C., Pfeffer, M., Dantas-Torres, F., Brianti, E., Deplazes, P., et al. (2015). The role of wild canids and felids in spreading parasites to dogs and cats in Europe. Part I: Protozoa and tick-borne agents. Vet Parasitol. 213(1-2): 24-37.

https://doi.org/10.1016/j.vetpar.2015.04.020

PMid:26049678

20. Cavallini, P., Santini, S. (1995). Age determination in the red fox in the Mediterranean habitat. Z Siiugetierk. 60, 136-142.

21. Mekaru, S. R., Marks, S. L., Felley, A. J., Chouicha, N., Kass, P. H. (2007). Comparison of direct immunofluorescence, immunoassays, and fecal flotation for detection of Cryptosporidium spp. and Giardia spp. in naturally exposed cats in 4 Northern California animal shelters. J Vet Intern Med. 21(5): 959-965.

https://doi.org/10.1111/j.1939-1676.2007.tb03049.x PMid:17939549
22. D’Ovidio, D., Rinaldi, L., Ianniello, D., Donnelly, T. M., Pepe, P., Capasso, M., Cringoli, G. (2014). FLOTAC for diagnosis of endo-parasites in pet squirrels in southern Italy. Vet Parsitol. 200(1-2): 221-224.

https://doi.org/10.1016/j.vetpar.2013.11.021

PMid:24389007

23. Perec-Matysiak, A., Buńkowska-Gawlik, K., Zaleśny, G., Hildebrand, J. (2015). Small rodents as reservoirs of Cryptosporidium spp. and Giardia spp. in south-western Poland. Ann Agric Environ Med. 22(1): $1-5$. https://doi.org/10.5604/12321966.1141359 PMid:25780818 